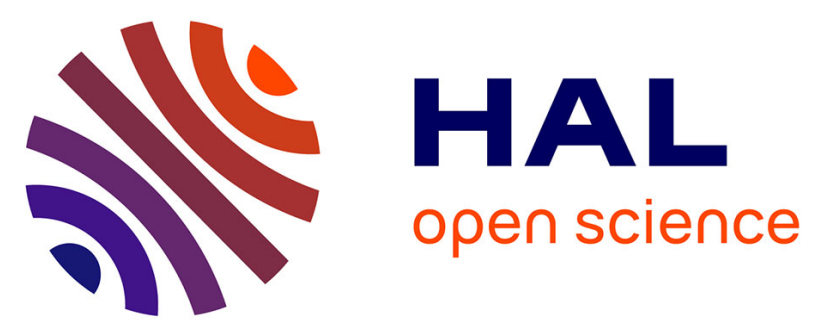

\title{
Broiler Meat Production in Piaui State: A Case Study
}

Eldelita Franco, Lilane De A. M. Brandão, José Luz, Kelly Gonçalves, Irenilza

De A. Nääs

\section{To cite this version:}

Eldelita Franco, Lilane De A. M. Brandão, José Luz, Kelly Gonçalves, Irenilza De A. Nääs. Broiler Meat Production in Piaui State: A Case Study. IFIP International Conference on Advances in Production Management Systems (APMS), Sep 2019, Austin, TX, United States. pp.116-122, 10.1007/9783-030-30000-5_15. hal-02419242

\section{HAL Id: hal-02419242 \\ https://hal.inria.fr/hal-02419242}

Submitted on 19 Dec 2019

HAL is a multi-disciplinary open access archive for the deposit and dissemination of scientific research documents, whether they are published or not. The documents may come from teaching and research institutions in France or abroad, or from public or private research centers.
L'archive ouverte pluridisciplinaire HAL, est destinée au dépôt et à la diffusion de documents scientifiques de niveau recherche, publiés ou non, émanant des établissements d'enseignement et de recherche français ou étrangers, des laboratoires publics ou privés. 


\author{
Broiler meat production in Piaui State: A case study \\ EldelitaA. P. Franco 1[0000-0002-8381-1583]; Lilane de A. M. Brandão ${ }^{2000-003-2506-6826]}$; José \\ A.A. Luz ${ }^{3 \text { [0000-0003-2326-5995]; Kelly L. F. Gonçalves 4[0000-0003-0565-0291] }}$, andIrenilza de A. \\ Nääs 5 [0000-0003-0663-9377] \\ Paulista University, São Paulo, Brazil \\ eldelitaaguida@gmail.com; lilanebrandao@gmail.com,josealberto@socimol.com.br; kel- \\ lyfg7@gmail.com; irenilza@gmail.com
}

\begin{abstract}
The state of Piaui is inserted in the broiler production chain in a significant way as a feed-ration supplierin a vastnew agricultural frontier. The present case study analyzes the evolution of a local company, as the Northeast presents itself as a promising market when comparing regional and national per capita consumption. For the present study, production costs were classified in the items of feed, labor, cost of capital, depreciation. Prices of the finished product (broiler meat) were investigated. Data included the production costs of broiler production from a commercial broiler farm. It was verified that the farm represents $63 \%$ of the regional production. Piaui state has emerged as a producer of soybeans and corn, and the slaughtered broiler of the largest producer pole is the southern region of Brazil. The transport is the main factor for raising the production costs of the meat supply chain.
\end{abstract}

Keywords:Brazilian meat production; broiler meat supply chain; meat market; logistics

\title{
$1 \quad$ Introduction
}

Poultry meat is the $2^{\text {nd }}$ world most consumed meat representing around 30 $\mathrm{kg} / \mathrm{capita} /$ year [1], and the increase in consumption by 2027 is forecasted to be near $35 \mathrm{~kg} / \mathrm{capita} /$ year. Such an increase in consumption comes from the less developed countries in Africa, Asia, and Latin America [2]. Globally 10\% of meat output in the next 15 years span will increase coming from poultry meat production sector. Import demand will be weak during the first years of the outlook period, mainly due to the slower growth in China, but will probably strengthen in the second half of the projection period, due to import growth in the developing world (Asian potential emerging countries such as Viet Nam) [3]. The growth of broiler meat consumption represents expansion and the development of other derived chains.

Brazil is a broiler production country with 1.4 million tons produced on average in the last years (2015-2018)[3]. The Brazilian exports added up to 625 million tons in 2018, and the forecast to 2028 might reach 5,178 million tons [4]. The forecast of annual growth projected for the Brazilian consumption of broiler meat is $2.6 \%$ in the period $2017 / 18$ to $2027 / 28$, meaning an increase of nearly $30 \%$ increase in consumption over the next ten years. The consumption of broiler meat projected for 2027/28 is a probable consumption of $56.7 \mathrm{~kg} / \mathrm{capita} /$ year [4].

The Brazilian Northeast region is undergoing a process of growth with little national representativeness, where only the State of Bahia stands out as the ninth position in the national production. Today the production profile of the region is focused almost entirely on domestic market. The state of Piauiis inserted in the productive broiler chain in two aspects, the first one as producer and consumer, with a consumption of $8.2 \mathrm{~kg} /$ capita in 2017. According to [5] the state is ranked second 
place as a supplier of feed-ration, within a vastnew agricultural frontier in Northeastern Brazil, currently in the $12^{\text {th }}$ position in the national ranking according to the report on the Brazilian grain harvest [6].

The current studycompares the information on the production costs of broiler amongst Brazilian regions. The present study analyzes the evolution of a local commercial broiler company, as the Northeast region has been evolving as a promising broiler meat market within the regional and national scenarios.

\section{$2 \quad$ Literature Review}

\section{Brazilian broiler meat production scenario}

Brazilian chain of broiler meat has been studied in several aspects [7] from the climate conditions of the country that favor the production, to the technological difficulties of investments in infrastructure and the dependencies of variations of the foreign exchange and commodities.

The economic crisis experienced in Brazil [8] in recent years has had a negative impact ongross meat consumption. The rise in unemployment and consequent reduction in the purchasing power of the population slowed down the domestic market. In parallel, there was a strengthening of exports, due to the Brazilian broiler health status, the professionalism of the productive chain, the exchange rate variation, and the product supply. In the year $2017,33 \%$ of Brazilian poultry production was exported. Brazil expanded its sales to countries that were not amongst the leading national importers, such as Chile.

According to the Brazilian Animal Protein Association [3], in 2017 the Brazilian production of broiler meat was 13.5 million tons, keeping the country in the position of the world's largest exporter and second largest producer of broiler meat, behind only of the United States. Data [3] showed that, of the total number of broilers produced by the country in $2017,66.9 \%$ were for domestic consumption and $33.1 \%$ for export. The broiler meat consumption in 2017 was $42.07 \mathrm{~kg} / \mathrm{capita}$ year,and total export volume was 4.3 million tons exported to more than 150 countries, with almost $40 \%$ participation in the world market of broiler meat

The industrial poultry sector employs more than 5 million people, directly and indirectly, and accounts for almost $1.5 \%$ of the national Gross Domestic Product (GDP). Thousands of integrated producers represent this sector, hundreds of processing companies, and dozens of exporting companies, which highlights its importance for the country [3]. The scenario of Brazilian production and consumption is shown in Table 1.

Table 1. Production and consumption of broiler meat in Brazil. 


\begin{tabular}{ccc}
\hline Year & $\begin{array}{c}\text { Broiler meat production } \\
(\mathrm{kg} / \text { capita })\end{array}$ & $\begin{array}{c}\text { Consumption } \\
(\mathrm{kg} / \text { capita })\end{array}$ \\
\hline 2018 & 63.10 & 43.32 \\
2017 & 62.83 & 42.78 \\
2016 & 62.62 & 43.25 \\
2015 & 64.04 & 41.10 \\
2014 & 62.70 & 42.07 \\
growth (\%) & 0.99 & 0.97 \\
\hline
\end{tabular}

Adapted from [3].

\section{Broiler meat supply chain and the production costs}

The production cycle in each house begins when the producer receives the 1-dayold chicks to grow until 43 days old when the birds reach $2.7 \mathrm{~kg}$. After that, the broiler is delivered to a cooperative that slaughters, processes, and markets the meat.

The studied commercial broiler farm has seven houses with an average capacity of 14 birds per square meter, which meet the required standards. Houses were equipped with lateral curtains and hadan automated system of lighting, ventilation, temperature control, and fogging.The broilers spend 43 days in an ideal environment for the development of the flock. The preparation for receiving the 1-day-old chicks in the rearing environment begins before the arrival of the birds, with the cleaning, disinfection of the house, verification of the perfect functioning of all the equipment ensuring the proper rearing environment. The development of the chicks, especially in the first week of life, is a necessary condition for the broiler performance, as the physiological development influences body weight and feed conversion at the age of slaughter [9]. Figure 2 shows the overall scheme of Brazilian broiler production chain.

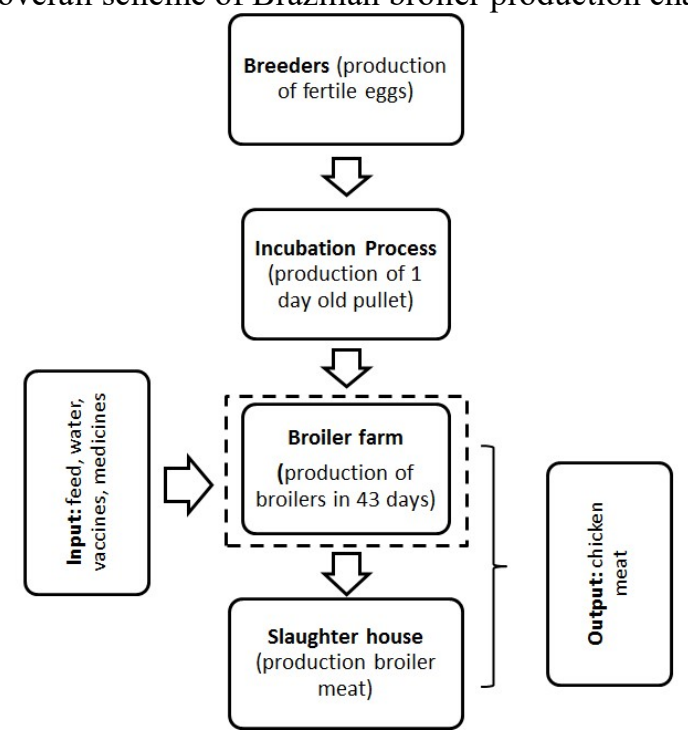

Figure 2. Brazilian broiler meat supply chain (adapted from [10]) 
The production process has a period of 60 days. Cost accounting generates management information to be distributed across the organizationto subsidize the operations' planning and control functions and the decision-making process [11]. Knowing the margin of the contribution of each product makes the manager has better control of the costs in the production process, thus maximizing profits and reducing the loss. The costs in broiler production are arranged according to the stages of the production process.

\section{Methods}

Data were recovered from January to December 2018. The sample studied is part of the production chain of acommercial broiler farm located in the metropolitan region of Teresina, in the State of Piaui (latitude -5.04 S longitude - 42.57 W). The total area has a housing capacity of $15,205 \mathrm{~m}^{2}$, distributed in seven houses where 625 thousand birds can be raised. The production process involved from receiving 1-day-old chicks to the delivery of grownbroilers to the local cooperative. Each cycle lasts 43 days with a 20-day interval for the period of health cleaning, adding up to a total of five annual cycles.

The present study was a case study, where the data were collected on the farm. Data were converted into spreadsheets, which involved the production costs of broilers during meat production. Production costs were classified according to the items: feed, labor, cost of capital, depreciation, and others. In the other sort, vaccines and medicines, maintenance, commercialization, and electric energywere included.

Spreadsheet software Excelwas used to compilingand processing the data. In the conversions of monetary values, the dollar exchange rate was used applying the arithmetic average of the considered periods (2017/2018). Prices of inputs and sales of the finished product were obtained, based on data from the local cooperative that receives the live broilers to slaughter. The production capacity was estimated according to the area of the houses considering a flock density of $14 \mathrm{birds} / \mathrm{m}^{2}$.

\section{$4 \quad$ Result and Discussion}

Overall global annual meat consumption per capita is expected to reach $35.3 \mathrm{~kg}$ by 2025 , an increase of $1.3 \mathrm{~kg}$ compared to the last 5 years period. This additional consumption will consist mainly of poultry meat, and nearly $90 \%$ is of broiler meat. In absolute terms, total consumption growth in developed countries over the projection period is expected to remain small relative to developing regions, where rapid population growth and urbanization remains the core drivers. According to [1] such a projection indicates an increase in thebroiler meat per capita consumption growth, when compared to the previous period (average 2015 to 2017), will increase by $2.8 \mathrm{~kg}$ in developed countries and by half of this amount in developing countries. Over the next decade, production will benefit somewhat from better feed conversion rate and somewhat from positive meat-to-feed price margins as well as better feed conversion ratios. Increased productivity will also lead to a positive supply response and lower meat prices for the projection period. Poultry meat remains the primary driver of the 
growth in total meat production, mainly in response to expanding global demand in the developing world. Low production costs, high feed conversion ratios, and low product prices have contributed to making poultry the meat of choice, both for producers and consumers.

Based on the projection of the poultry market, Brazil is the world largest export market and the second largest producer [12]. The South region is characterized as the main producing region of the country, in the Northeast, the production of greater relevance is the state of Bahia occupying the 9th position with a total of 269 thousand birds in 2017.

It was verified, in the field research carried out, that the farm has an installed capacity of 625 thousand broilers/year, and suchproduction represents $62.7 \%$ of broiler production in the municipality of Altos [5]. It was observed that it presents a guarantee of full consumptionby the domestic market, confirmed by [3]. The report indicates that the State of Piaui is ranked $18^{\text {th }}$ in the ranking of broiler production in Brazil, but it is not noted at the national level as an export market, as shown in Figure 1.

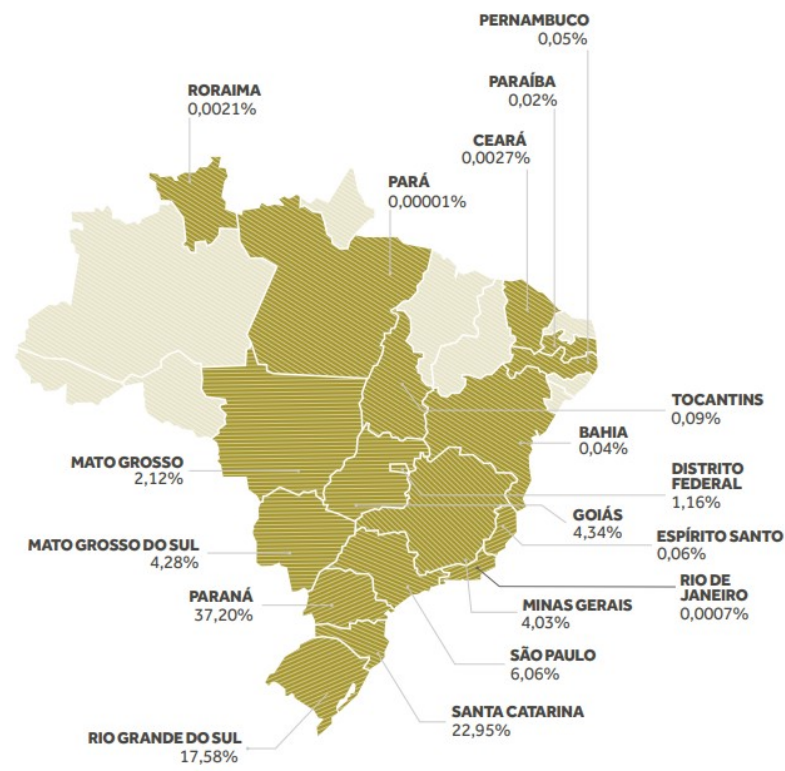

Fig. 1. Brazilian states producers of broiler meat and the corresponding percentage of production in 2017. Source: [3]

The feed-ration represents $70.92 \%$ of the production costs of the farm, and four feed compositions are available according to the growth period. Feed management begins with the use of $0.20 \mathrm{~kg} /$ feed-ration for the bird in the first five days. Immediately after this period the initial feed is introduced for 21 days, allowing the consumption of $1 \mathrm{~kg} / \mathrm{bird}$, following the phase of growth for 10 days with the use of $2.2 \mathrm{~kg}$ of growth ration, closing the cycle with $0.9 \mathrm{~kg}$ of finishing ration in the last seven days of a cycle of 43 days. After the harvest of the birds for slaughter, the 
houseundergoes into the process of sanitarycleaning, which ensures full sanitation and disinfection to receive a new flock after 20 days.

Due to its installed capacity, the area allows the production of 14 birds per square meter, a parameter that used in the Brazilian production process, which can vary from 12 to 18 head per square meter [13]. When analyzing the costs of production of a year, it was verified that it had an average cost/bird of US\$2.11, which when compared to the cost of production of US\$2.00 in the Southern region of Brazil. It is believed that in the case of the region of the largest production in the country, the scale of production influences the difference in cost of production in the order of $5.5 \%$.

The AVIPE - Pernambuco Poultry Association [14] presents an analytical study of datametricsthat evaluate the poultry meat chain of the Northeast Brazilianregion, andassure that it should at least triple its production to fulfill the regional consumer market. The broiler production chain is growing on a large scale at the national level. In the Northeast, the consumption is $10.40 \mathrm{~kg} / \mathrm{capita}$, not yet reflecting the local consumption of $43.32 \mathrm{~kg} / \mathrm{capita}$. Given this perspective, the interest of growth in the productive capacity of the studied company is justified in order to reduce the average cost with the expansion of productive capacity by $70.92 \%$, taking advantage of the economies of scale available in the years 2018 and 2019. The research sample suggested that the increase in production leads to better use of the economy of scale. However, the difficulties in the expansion of production in mostbroiler farms are related to the limiting factors of area and labor. Ina proper scale,there is a trend to pressure market pay-off for better price negotiations to make the activity viable.

The larger the scale of the business, the production operations facilitate the logistics of technical and veterinary assistance, as well as the supply of feed and 1-day-old chicks, in addition to negotiations of other inputs such as energy and maintenance. It is also allowed the poultry farmers to participate in the system of partnership with the agroindustry making the investments needed for production.

Table 1 presents the main costs that correspond to the selling price of broiler. The feed is the most relevant item, representing $76.4 \%$ of the total costs.

Table 1. Broiler meat production cost

\begin{tabular}{lllll}
\hline $\begin{array}{l}\text { Expenses } \\
(\mathbf{1 0} \wedge \text { 2 US\$) }\end{array}$ & National/2018 & National/2017 & Local/2018 & Local/2017 \\
\hline Feed ration & 51.44 & 57.02 & 64.63 & 64.79 \\
Labor & 4.65 & 5.13 & 1.52 & 2.12 \\
Capital cost & 1.37 & 1.51 & 4.23 & 4.22 \\
Depreciation & 1.64 & 5.73 & 1.20 & 1.34 \\
Other & 14.78 & 16.29 & 18.71 & 18.32 \\
Total & 73.88 & 85.69 & 90.29 & 90.79 \\
\hline
\end{tabular}




\section{$5 \quad$ Final remarks}

Given the complexity of the market dynamics and because broiler meat is a commodity, there is a significantinternational oscillation of the purchase value. Because Piaui state is emerging as a producer of soybeans and corn,which are the primary input products of broiler feed-ration, producing broiler meat in the region should remain profitable. Such condition decreases the transport of raw material for processing the feed. It is also worth mentioning that in the case of buying the slaughtered broilers from the largest producer pole that is the southern region of Brazil, the average road distance would be approximately $3,000 \mathrm{~km}$ from the state capital (Teresina), where logistical costs appears as a determinant factors for raising the costs of broiler meat for the local market.

\section{References}

1. OCDE-FAO Agricultural Outlook 2018-2027, Chapter 6. Meat. Available at: http://www.fao.org/3/i9166e/i9166e_Chapter6_Meat.pdf. Accessed at: March 18, 2019.

2. FAO- Food and Agricultural Organization. 2016. Available at: http://www.fao.org/3/aBO100e.pdf. Accessed March 18, 2019.

3. APBA - Associação Brasileira de Proteína Animal (2017). Available at: http://abpabr.com.br/storage/files/3678c_final_abpa_relatorio_anual_2016_portugues_web_reduzido. pdf. Accessed on: March 18, 2019.

4. MAPA- Ministério da Agricultura, Pecuária e Abastecimento, Secretaria de Política Agrícola. Available at: http://www.agricultura.gov.br/assuntos/politica-agricola/todaspublicacoes-de-politica-agricola/projecoes-do-

agronegocio/PROJECOES2018_FINALIZADA_web_05092018.pdf. Accessed March 18, 2019.

5. IBGE-Instituto Brasileiro de Geografia e Estatística. 2018. Available at: https://cidades.ibge.gov.br/brasil/pi/pesquisa/18/16459. Accessed on: March 19, 2019.

6. CONAB - Companhia Nacional de Abastecimento. 2018. Available at: https://www.conab.gov.br/info-agro/safras/graos. Accessed on: March 19, 2019.

7. Schmidt, N. S.; Silva, C. L. Pesquisa e Desenvolvimento na Cadeia Produtiva de Frangos de Corte no Brasil. Revista de Economia e Sociologia Rural, v. 56, n. 3, p. 467-482, 2018.

8. De Souza, A. D. et al. Crise mundial de 2008 e adoção de políticas econômicas pelo governo brasileiro. Revista de Ciências Empresariais da UNIPAR-RECEU, v. 18, n. 1, 2018.

9. Sousa, P.Avicultura e clima quente: como administrar o bem-estar às aves. Avicultura Industrial, v.96, n.1133, p.52-58, 2005.

10. Nääs, I.A., Mollo Neto, M., Canuto, S. A.,Waker, R., Oliveira, R. M., Vendrametto, O. Brazilian chicken meat production chain:a 10-year overview. Brazilian Journal of Poultry Science., v. 17, p.87-94, 2015.

11. Leone, G.S.G.Curso de contabilidade de custos ABC: 2. Ed. São Paulo: Atlas, 2000.

12. EMBRAPA- Empresa Brasileira de Pesquisa Agropecuaria (2018). Available at: https://www.embrapa.br/suinos-e-aves/cias/estatisticas. Accessed on March 18, 2019. 
13. Avisite. Planejamento e Local da Produção -Viabilidade Econômica do Projeto Availableat: https://www.avisite.com.br/cet/trabalhos_versao_imprimir.php?codigo=33, Accessedon: 19.03 .2018

14. Avicultura Industrial.

2015.

Available at:https://www.aviculturaindustrial.com.br/imprensa/nordeste-pode-triplicar-suaproducao-avicola-diz-estudo/20150219-165017-d465. Accessed on: March 20, 2019.Porto de Santos. Available in: http://www.portodesantos.com.br. Accessed in August 17, 2018. 